\title{
Constructing (II)Legitimate Democracy: Populism and Power Concentration in Newspaper Discourse on Venezuela
}

\section{Ernesto Abalo}

\author{
School of Humanities, Education and Social Sciences, Örebro University, Örebro, Sweden, \\ ernesto.abalo@oru.se, http://www.oru.se/humus/ernesto_abalo/
}

\begin{abstract}
Despite scholarly consensus about the importance of the media for democracy, scant attention has been paid to what democracy means to journalistic discourse and how discourses on democracy are interrelated with legitimacy. The aim of this paper is to explore how (il)legitimate democracy is constructed in newspaper discourse. By using critical discourse analysis (CDA), this paper examines foreign news items about Venezuela, a country that under the presidency of Hugo Chávez has challenged the dominant global political and economic orders. The analysis section focuses on two discourses about the Venezuelan government: the constructions of populism and power concentration, which serve to mark deviance from what is perceived as a legitimate democracy. This paper argues that a liberal perception of democracy constitutes a central framework for the construction of (il)legitimate democracy, which is revealed not least by news discourse's focus on what is morally unacceptable political conduct according to liberal democratic norms. In this respect, the media discourse serves to denounce potential abuses of governmental power but fail to recognize democracy in the context of a social struggle against the effects of neoliberalism and capitalism. In this case, the news media is hegemonic in the Gramscian sense, because it provides a framework of democracy that remains within the dominant economic and political structures.
\end{abstract}

Keywords: Democracy, Media, Discourse, Hegemony, Ideology, Legitimacy, Liberalism, Critical Discourse Analysis, Foreign News, Venezuela, Hugo Chávez

Acknowledgements: I would like to thank my supervisors Leonor Camauër and Ulrika Olausson, as well as the two reviewers for insightful comments that helped me improve this paper.

\section{Introduction}

French philosopher Alain Badiou argues that democracy has become the "dominant emblem" of contemporary political discourse (Badiou 2011,6-7). Everyone seems to salute democracy, and there seems to be no exception in media and communication research. The claim that the media play a pivotal role in the democratic process has become something of an axiom within communication studies-a claim with enough force to bring together scholars from different theoretical currents (e.g., Curran 2011; Fenton 2012; McChesney 2013; McNair 2007; Strömbäck 2005). Although there are scholarly disagreements about how the media should relate to states and markets to enrich democracy, there is a shared belief that the media, through its content and practices, can affect democracy. Apart from theoretical discussions on the matter, this general view is also recurrent in empirical studies on journalism, especially in political communication where election reporting content analysis is of central interest (Aalberg, Strömbäck, and de Vreese 2012; Dimitrova and Strömbäck 2012; Gan, Joo, and Detenber 2005; Hopmann, Van Aelst, and Legnante 2012). Such research emphasizes how media content can potentially condition an ongoing democratic process.

In contrast to much of the previous empirical work on media and democracy, this paper explores how democracy is constructed discursively in the media. The study centers on the notion that democracy, apart from being an ongoing social and political process, is also to a great extent the outcome of discursive practices and struggles. In our contemporary world, democracy not only names and explains a given political order, but in the ways in which it is explicitly and implicitly defined and used, it also serves to argue for and legitimize certain 
actors, values and practices. Democracy is an important ingredient in the self-image of the West (Amin 1989, 107), as well as in liberal ideology where democracy is paired with capitalism (Amin 2004, 42-51). Also, as Farrelly (2008, 426-427) argues, democratic discourse is sometimes used in contemporary politics to legitimize non-democratic actions, something that is made possible because "the concept of democracy has become emptied of much of its content" (Farrelly 2008, 427). A clear example of this is the use of democracy discourse to legitimate for military intervention (Chomsky 2006, 128-165).

More specifically, this paper aims to explore how (il)legitimate democracy is constructed in newspaper discourse, or the ways in which specific political governments or systems are constructed as legitimate or illegitimate in relation to a perceived notion of democracy. Empirically, it studies foreign news discourse about Venezuela, a country that under Hugo Chávez's presidency has challenged the global dominant order in economic and political spheres. Economically, the Venezuelan government has sought to reduce poverty by moving away from a neoliberal economic model and instead establishing a nationalist and somewhat socialist-inspired substitute. Politically, Venezuela has challenged the traditional characteristics of a liberal democracy, partly by introducing elements of participative and radical democracy that emphasizes social justice and direct forms of participation (Buxton 2011; Ellner 2008; Ellner 2010; Smilde 2011). Venezuela's movement away from a liberal democracy, however, has led to charges of authoritarianism (Human Rights Watch 2008). Given that Chávez's Venezuela has challenged the dominant economic and political fundamentals of the world order, yet relied on strong popular support through several landslide electoral victories, news on Venezuela can provide important insights into the underlying ideological perceptions of media discourse on conceptions of (il)legitimate democracy.

This study aligns itself with a dispersed body of media research that focuses on the relationship between democracy, ideology and legitimacy. This research has stressed the importance of elite ideology in how the media constructs foreign political subjects and events as compatible with democracy (Garyantes and Murphy 2010; Herman and Chomsky 2002, 87142; Kim 2000); it has given insight into how discourses on democracy, among others, are intertwined with the legitimization of a neoliberal world order (Moyo 2010) and of US national interests (Duncan 2012).

This study makes an important contribution to the field by showing how discourses on populism and power concentration serve to construct deviance in opposition to what is perceived as legitimate democracy. Moreover, the study argues that such discourse reveals the presuppositions of liberal conceptions of democracy. In this sense, constructions of (il)legitimate democracy serve to denounce potential abuses of governmental power but fail to recognize democracy in the context of a social struggle against the effects of neoliberalism and capitalism.

Next, the study's theoretical framework is presented, a section that is followed by the presentation of methods and empirical materials. Subsequently, the study's results are accounted for. The paper concludes with a discussion of the relationships among discourses on democracy, legitimacy and liberalism, along with a brief suggestion for how future research can develop further understanding of democracy as a discursive media practice.

\section{Theoretical Framework}

Following the principles of critical discourse analysis (CDA), this paper is interested in how democracy is discursively constructed in the media. Discourse is here understood as "language use in speech and writing", which in turn is a form of "social practice" (Fairclough and Wodak 1997, 258). Furthermore, discourse is understood as situated in a dialectical relationship with its sociopolitical context, which means that language use can both shape and be shaped by its context (Fairclough and Wodak 1997; Wodak 2001). In turn, the study argues that discourse constitutes a type of soft power that serves to legitimize or delegitimize specific structures and practices. Following Chouliaraki's (2005, 3) discussions on the Iraq war, legitimacy is conceived as constructing something as "legally and morally acceptable". Discourses' ability to construct (il)legitimacy is an aspect of their ideological workings. 
The ideological workings of discourse are best explained when conceptualized as part of what the Italian communist intellectual Antonio Gramsci (1971) calls hegemony. According to Gramsci, the ruling classes in capitalist societies exercise power primarily through hegemony, which is a form of "intellectual and moral leadership" (Gramsci 1971, 57). Unlike domination, which according to Gramsci is exercised through coercion, hegemony requires the consent of the dominated. This difference, in turn, makes ideological struggles highly significant for the purpose of securing consent among the population, given that people "acquire consciousness of structural conflicts on the level of ideologies" (Gramsci 1971, 365).

Fairclough stresses that discourse is connected to hegemony in two ways. "On the one hand", says Fairclough, "hegemonic practice and hegemonic struggle to a substantial extent take the form of discursive practice, in spoken and written interaction" (Fairclough 1995, 94). Moreover, Fairclough emphasizes that a "particular set of discursive conventions (e.g. for conducting medical consultations, or media interviews, or for writing crime reports in newspapers) implicitly embodies certain ideologies", including "particular knowledge or beliefs" and "particular relationships between categories of participants" (Fairclough 1995, 94). Following Fairclough's argument, the naturalization of such discursive conventions inevitably leads to the naturalization of the ideological presuppositions, making such naturalized conventions "a most effective mechanism for sustaining and reproducing cultural and ideological dimensions of hegemony" (Fairclough 1995, 94). Therefore, according to Fairclough's thesis, the process of denaturalizing certain conventions that are taken for granted is central to a hegemonic struggle.

The second part of the relationship between discourse and hegemony "is that discourse is itself a sphere of cultural hegemony", and the hegemony of a group "is in part a matter of its capacity to shape discursive practices and orders of discourse" (Fairclough 1995, 95). Likewise, the hegemony of a group "is constituted by a more or less unstable equilibrium between its constitutive discursive practices, which may become unbalanced and open to being restructured in the course of hegemonic struggle" (Fairclough 1995, 95). Thus, hegemony is not definitive, but determined by the outcome of social and ideological struggles between opposed groups. While "dominant forces" will try to "preserve or restructure and renew their hegemony in the sphere of discourse", dominated groups will try to contest that hegemony (Fairclough 1995, 95).

To understand democracy as an ideological discourse and its role in hegemony, one has to socio-politically and historically contextualize it. The end of the Cold War saw the triumph of the West, and with that the expansion of capitalism as a global economic model and of liberalism as ideology. With the defeat of the socialist camp, Bensaïd argues, "the floating signifier democracy became a synonym for the victorious West, the triumphant United States of America, the free market, and the level playing field" (Bensaïd 2011, 17-18). Bensaïd's claim can at first instance seem exaggerated but by contextualizing democracy within the framework of liberal ideology, the statement appears to be more reasonable.

The post-Cold War era, or the era of globalization as some label it, is not only characterized by free-market capitalism or neoliberalism, but as Cannon $(2009,205)$ notes, by the interrelationship of that economic structure and liberal democracy as a political structure. As "really existing democracy" (Cannon 2009, 24), liberal democracy arguably reduces the people's rule to the structures and practices of that liberal form of governance. Perceived democratic fundamentals then include the state's separation from civil society, the state's formation as an impersonal legislative power structure, the protection of individual liberties (as freedom of speech and expression) and the existence of party pluralism (Held 2006, 268). However, as Held argues, "liberalism's thrust to make a democratic state ... is compromised by the reality of the 'free-market"', and a central weakness "is to see markets as 'powerless' mechanisms of coordination, and thus to neglect [...] the distorting nature of economic power in relation to democracy" (Held 2006, 269). Furthermore, this form of democracy "leaves untouched vast areas of our daily lives-in the workplace, the distribution of labour and resources-that are not subject to democratic accountability" (Roper 2013, 238). As Macpherson notes, the word liberal in liberal democracy "has consciously or unconsciously been assumed to mean 'capitalist"' (Macpherson 1977, 2), and the democratic model itself has "been 
designed to fit a scheme of democratic government onto a class-divided society" (Macpherson 1977, 9). Moreover, Macpherson points out that liberal democracy as practiced in the twentieth century, and as theorized by Schumpeter, is highly elitist because it "assigns the main role in the political process to self-chosen groups of leaders" (Macpherson 1977, 77). According to such a model, democracy becomes a mechanism for choosing governments, and the voter's role is to choose between elites in the form of politicians or parties that will carry out decisions. This model stands in contrast to one that lets the people decide political issues first and then elect appropriate representatives (Macpherson 1977, 78). Thus, democracy becomes "simply a market mechanism: the voters are the consumers; the politicians are the entrepreneurs" (Macpherson 1977, 79).

This model seems to be ideologically justified based on its guarantee of specific rights and liberties to citizens and its provision of some degree of political stability. Moreover, the model promises to protect against tyranny and totalitarianism, because the pluralism inherent in liberal democracy enables the electorate to vote for a new government in the next election (Macpherson 1977, Pateman 1970). Furthermore, the liberal democratic framework's protection of markets and private economic power thus encourages opposition to interventions against capitalist principles-interventions cast as restrictions on individual liberties. As Amin notes, in a historical context where liberal ideology is strong and social criticism weak, "democracy can be emptied of all content which restricts and is potentially dangerous for the market" (Amin 2004, 46). In this way, liberal ideology can dismiss alternative forms of democracy that challenge the market, and fix the meaning of democracy as to legitimize capitalist principles. When referring to capitalism one has to perceive it in a global context. The global expansion of capitalism "cannot occur by the force of economic laws alone; it is necessary to complement that with political support (and military, if necessary) from states in the service of dominant capital" (Amin 2004, 23). It is in such a context that one should evaluate the use of democratic discourse in legitimizing the 2003 invasion of Iraq by the United States. Significantly, after that the primary argument used to legitimate the invasion-that Iraq's possessed weapons of mass destruction-was proven false (Chomsky 2006, 128-165). As Farrelly notes, such is possible when democracy is emptied from its meaning, and at the same is paired with an abstract notion of global values, which in the end serves to legitimize the imposition of 'democracy' on others through interventions (Farrelly 2008, 419).

Liberal understandings of democracy have not remained uncontested, however. I will briefly account for two other democratic models that serve to problematize the theories and practices of liberal democracy: participatory democracy and radical democracy.

Based on their critique of the elitist character of liberal democracy, scholars such as Macpherson and Pateman have called for and theorized additional participatory forms of democracy. Participatory democracy, according to Pateman, is centered on the notion "that individuals and their institutions cannot be considered in isolation from one another" (Pateman $1970,42)$, and that the established representative institutions are not sufficient for democratic action. Instead, the participation of the citizens is required not only for decision-making but also to socialize and develop the individual. "The major function of participation in the theory of participatory democracy", writes Pateman, "is therefore an educative one, educative in the very widest sense, including both the psychological aspect and the gaining of practice in democratic skills and procedures" (Pateman 1970, 42). The educative effects of participation would, in turn, determine the stability of the democratic system. Participatory democracy, however, does not necessarily exclude representation. Macpherson argues, for example, that at a national level some sort of representative form of democracy is needed. Direct forms of democracy are appropriate at the neighbourhood level and in workplaces, where high levels of participation and decision-making are involved. This direct participation could be combined with the election of delegates to councils, and the delegates would be held responsible to those below (Macpherson 1977, 95, 108-109). Moreover, drawing on the ideas of Rousseau, advocates of participatory democracy not only see political equality as a prerequisite for democracy, as is the case in liberal theory, but also give central importance to social equality. This follows Rousseau's argument that high levels of social inequality lead to political inequality (Pateman 1970, 22-23). Political equality in the theory of participative de- 
mocracy is measured not only in terms of specific rights, but also in terms of the "equality of power in determining the outcome of decisions" (Pateman 1970, 43). This aspect clearly distinguishes participatory democracy from liberal democracy.

Radical democracy stems from a critique of liberal democracy, particularly as it is practiced under neo-liberalism. Radical democrats like Mouffe are not primarily critical of the political fundamentals of liberal democracy, such as its guarantees of specific rights, but they object to the failure of liberal democracy to realize its promises. Mouffe even endorses the claim that the only acceptable means of reaching socialist goals is through a liberal democratic government (Mouffe 1992, 1-2). The idea of a radical democracy is thus to deepen democracy. Unlike liberals, radical democrats do not defend capitalism; according to Mouffe, one must distinguish and separate political liberalism from economic liberalism. Additionally, radical democrats advocate moving beyond liberal individualism. In its place, they stress the need to reinstate the notion of the citizen as a person who is active and integrated in a community that defends "the plurality of forms of identities through which we are constituted and which correspond to our insertion in a variety of social relations" (Mouffe 1992, 5). In this sense, the radical democratic project is a means of achieving social justice as well as countering what is perceived as the watering down of democracy under neo-liberalism.

The models of participatory democracy and radical democracy, particularly their focus on participation, social justice and the disentanglement of democracy and capitalism, thus serve to problematize the dominant liberal understanding of democracy. Compared to these models, liberal democracy provides rather limited opportunities for participation and serves to reproduce social inequality through its embrace of capitalism. Liberal democracy, at least as practiced in many Western countries, is a limiting form of government for a political project that aims to provide social justice and implement the self-determination of the people.

It is in such a context that one should evaluate the political process that was initiated by Chávez in Venezuela, also known as the Bolivarian Revolution. Expanding participatory democracy is an aim of the transformation of Venezuela from a capitalist state to one with a socialist orientation (Artz 2012, 538). This transformation places an emphasis on the "participation of popular sectors of the population" and on "mass mobilizations" to enable "empowerment, incorporation, and 'political learning' on the part of the formerly excluded" (Ellner $2010,80)$. As Lebowitz notes, human development is a topic that is reflected in the Bolivarian Constitution, and participation, both in a political and economic sense, is the preferred method for achieving this (Lebowitz 2010, 14-15). As Ellner notes, the Bolivarian Constitution, passed by popular vote in 1999, attempts "to curve political party hegemony and transfer power to social movements" and calls for the state "to 'facilitate' popular input in decisionmaking" (Ellner 2008, 177). Constitutional mechanisms to increase participation include "referenda, the participation of civil society in the nomination processes of public officials, and incentives for local organizations that can make demands of the government" (Smilde 2011, 8). Moreover, the government has supported social organizations such as the Urban Land Committees and community media organizations (Smilde 2011, 8). An important example of the power of participation was seen in 2004 when Chávez himself faced a recall referendum initiated by an oppositional signature campaign; the initiators of the referendum, however, lost by a wide margin (Cannon 2009, 117). Consistent with the principles of radical democracy, Chávez supporters have worked to ensure that decisions made by direct popular participation "are binding and that they take precedence over or displace representative institutions such as the Congress and political parties" (Ellner 2008, 178). However, as Ellner notes, the success of the Chávez government ultimately depends on which democratic model that one uses to evaluate it. If judged by the standards of participatory or radical democracy, the Chávez government appears to have done quite well (Ellner 2010). In addition to politically mobilizing formerly excluded segments of the population, the Chávez administration witnessed a decrease in poverty and extreme poverty during its first ten years in power (Weisbrot and Ray 2010, 9). Chávez also increased social spending and implemented social programs that provided free health care and subsidized food (Weisbrot and Sandoval 2007). However, if judged by the standards of a liberal democracy, which the opposition in Venezuela more closely resembles, there are clear shortcomings. For example, people who are Chávez- 
partisans, such as members of the electoral council, the attorney general and the national controller, hold key positions that are intended to be politically non-partisan. This partisanship has resulted in a lack of institutional checks on power. The Chávez government, like its predecessors, continues to disregard the non-partisan nature of public administration. Additionally, the Venezuelan Constitution has strengthened the power of the executive in some instances (Ellner 2010, 79-80), indicating that Venezuelan democracy is complex and difficult to evaluate according to a sole democratic model. Moreover, one must keep in mind that Chávez's revolutionary movement gained momentum due to the failures of the former governments' neoliberal policies, which left the vast majority of the population in poverty. Additionally, the former elitist democratic system had lost legitimacy among a majority of the people (Cannon 2009, Ellner 2008).

When studying the relationship between discourses on democracy and the media, it is important to contextualize the media as institutions that, at least in the West, possess a selfimage as defenders of democracy - while operating as capitalist enterprises that for the most part depend on advertising revenues (Fenton 2012; Fuchs 2011). Critical scholars argue that the mainstream media's economic basis, in combination with a taken-for-granted attitude toward bureaucratic societal organization, make the media dependent on elite sources, who are in an advantageous position to frame news in accordance with their perspectives and interests (Allan 1999; Herman and Chomsky 2002). Despite variations, news discourse, especially that of newspapers, tends to be centered on the "'consensus of values' representing the ideological limits of 'reasonable opinion'”, something that is in line with the perspectives and interests of powerful groups (Allan 1999, 89). In this sense, as Herman and Chomsky (2002) point out, mainstream news media tend to give preference to perspectives that take Western free-market capitalism for granted. Such imbalances may also be apparent in news reports on foreign events, as media outlets are to a high degree dependent on news agencies. Given the dominance of a few Western agencies, the information risks being shaped to fit Western interests (Boyd-Barrett and Rantanen 2004; Thussu 2004). In the current study, these factors are important to consider because the news media's structural context can indeed condition how (il)legitimate democracy is constructed and can thus favor democratic perceptions that are coherent with Western political and economic norms and practices. However, these factors need to be empirically studied to better understand the relationship between democracy and legitimacy in media discourse.

\section{Methods and Materials}

This study relies on 60 newspaper items from Dagens Nyheter (DN, Sweden, 16 items), El País (EP, Uruguay, 23 items), and the New York Times (NYT, US, 21 items), that all reports on events in which Venezuelan politics are central. The newspapers were chosen as elite newspapers from different geopolitical contexts but without the intention of comparing the outlets. Elite newspapers were chosen because of their impact in influencing public discussion of political matters, as well as providing a form of social knowledge, which at least according to the journalistic professional ideology aims to be impartial (see Allan 1999). In order to minimize any potential bias due to the historical and sociocultural specificities of the context in which a newspaper is situated, different geopolitical exponents where chosen.

Apart from being a (if not the) leading newspaper in the world, the choice of the $N Y T$ is grounded in the ambition to include a daily from the world's only superpower, which has a major influence on global politics. The NYT does not declare any specific editorial political stance, and stresses that its goal is "to cover the news as impartially as possible" (New York Times 2014). DN was chosen for being a leading newspaper in Sweden, a country that historically has upheld the principles of neutrality and has had a positive attitude towards progressive countries and movements of the Global South. $D N$ declares its editorial stance as "independently liberal", and as standing "free from parties, organizations and economic spheres of influence" (Dagens Nyheter 2014). ${ }^{1}$ EP, in turn was chosen in order to enable

\footnotetext{
${ }^{1}$ All quotations and excerpts from non-English languages have been translated by the author.
} 
collection of foreign news on Venezuela from a leading newspaper of another South American country, which shares a colonial past with Venezuela, and to some extent, also its present social structures. EP belongs to a conservative political tradition (Achugar 2004, 293). Because these newspapers represent countries with dissimilar sociocultural heritages and different foreign policies, they potentially offer a broad spectrum of themes and perspectives (see Olausson 2013), despite the fact that each of the newspapers has a politically right oriented editorial board.

Two periods were chosen for retrieving data: November/December 2007 and March 2013..$^{2}$ The first period was chosen because Venezuela was then in the midst of campaigns and debates about a constitutional reform proposal, which was rejected by a minimal electoral margin that December. Because the proposal, authored by president Hugo Chávez and the National Assembly, involved constitutional changes that to a great extent challenged liberal democratic principles, media coverage from that period could provide important insights into the construction of (il)legitimate democracy. The second period was chosen because it was the month of Chávez's death. Given Chávez's premier importance in Venezuela's political transformation, as well as the recent left-turn of Latin American politics, the selected period could potentially offer materials that assess Chávez's political achievements and shortcomings. As a first step, all published news items from these newspapers during the in question periods were collected. The next step involved the careful selection of items in an effort to gather a myriad of themes that inform democracy, as well as to have a convenient sample for qualitative analysis. ${ }^{3}$

All of the items are to be regarded as falling within the foreign news genre, yet discourse types vary. Apart from regular news articles, the materials also include briefs and freer journalistic analyses/commentaries. Only verbal language was considered for analysis, and info boxes and other complementary news article elements were excluded.

This analysis has been guided by van Dijk's (1988) discussions on news as discourse; the overall aim is to grasp the topics, or macropropositions, present in the selected news items. These items were analyzed both at the macro- and micro-level. Macro-level analysis involved the identification of the texts' main topics and the schematic structure of each item. Macropropositions are, however, realized in the text's microstructure, and the analysis has at the micro-level sought the following microstructural elements:

- Local and global coherence. How are different propositions connected to each other, and what are the conditional relations between a text's stated facts and its global meaning?

- Implicit and omitted information. What substantial information is either implicit or omitted in the text, and what are the consequences for the meaning of the reported occurrences?

- Choice of quotations. What actors are quoted in the texts, and what implications do the chosen quotations have for the meaning of the reported occurrences?

- Semantic style. Which lexical choices, such as categorizations and epithets, are used for describing actors and/or occurrences, and what implications do these have for the meaning of the text?

Subsequently, macropropositions that shared specific thematic characteristics were grouped together into larger topic classes.

The analysis has sought discursive patterns, rather than discursive differences, in the construction of (il)legitimate democracy. It is pivotal to note that CDA is a highly interpretative method and that the reader can test the arguments' validity and reliability by reviewing the quotations and excerpts provided in the text (Olausson 2013,3).

\footnotetext{
${ }^{2}$ Different methods were used to retrieve the materials. The NYT materials have been retrieved through the database ProQuest by searching for Venezuela and Chávez. The DN materials have been retrieved by searches for Venezuela and Chávez in the database Retriever. Reading hardcopy newspapers has also complemented this retrieval. The EP materials have been retrieved at the National Library in Montevideo and by collecting hardcopy newspapers.

${ }^{3}$ The materials from 2007 contain 8 items from DN, 12 from EP and 11 from the NYT. The materials from 2013 contain 8 items from DN, 11 from EP and 10 from the NYT.
} 


\section{Results}

This section presents the study's results and is structured around two discourses found in the analysis: 1) the construction of populism and 2) the construction of power concentration. Both findings relate to the Venezuelan government and the discourse serves the construction of deviance from what is considered legitimate according to a liberal-ideological perception of democracy.

\subsection{Populism}

In everyday speech and in media discourse, populism, a rather vague word that social scientists use to conceptualize government appeals to the people against an elite (Andersson 2009; Cannon 2009; Laclau 2007), is used as an invective to connote deviance from an allegedly pure or traditional democracy. Although its vagueness has caused disagreements about whether populism in media discourse signifies a "pathology of democracy" (Mény and Surel 2002,3 ) or more generally refers to political leadership that uses cheap tactics to rally support (Andersson 2009), it nevertheless has a negative signification. As D'Eramo claims, "In its most brutal form, 'populist' is simply an insult; in a more cultivated form, a term of disparagement" (D'Eramo 2013, 8). The term populism has traditionally, yet inconsistently, been applied to actors who for instance are perceived as deviating from conventional forms of democracy, who in some way stress the leadership of the people, or who are characterized by charismatic and/or authoritarian leadership (see Andersson 2009; Cannon 2009; Mény and Surel 2002). For example, dissimilar Latin American politicians Juan Domingo Perón, Alberto Fujimori and Hugo Chávez have been labeled populists.

In this section, I will present two ways in which discourse on populism appears in the selected material. The first relates to direct constructions in which political agents are denominated populists, and the second regards indirect constructions in which the Venezuelan government appears as acting in accordance with populist logic. The presented discourses serve to construct deviance from that which is to be regarded as a legitimate democracy, thus revealing liberal presuppositions about democracy.

\subsubsection{Direct Constructions of Populism}

On one level, discourses on populism can be observed in the semantic style that EP and the NYT employ in reference to the Venezuelan government. For example, the terms "populism", "populist", "populist politics" and "populist proposals" are used in direct relation to Chávez. An $E P$ article reflects on the meaning of the term, saying, "Populism is an evasive term, many times used as synonymous to abuses of duties. However, one of its characteristics is to appeal to the basic instincts of the voters" (EP7). This reflection implies that the term's use in media discourse can imply power abuse but that it also can have a more general signification.

Although the term "populist" is rather vague, the ways in which the term coheres with its discursive context opens up the meanings of deviance. The NYT, for example, writes that "For nine years, a combination of populist politics and rising oil prices have propelled Mr. Chávez's socialist program for Venezuela with an almost inexorable momentum" (NYT10). Here, "rising oil prices" supports "populist politics" and explains Chávez's popularity, downplaying his eventual sincere intentions of reducing poverty and the successful social policies that could potentially explain his popularity. Apart from witnessing a reduction of poverty (Weisbrot and Ray 2010, 9), the Chávez administration has increased social spending in the areas of education and health care and provided subsidized food (Weisbrot and Sandoval 2007). Such measures directly affect the living conditions of the poor. If one changes "populist politics" to, for example, social politics, or progressive politics, it becomes evident that the term "populist" invites questions of legitimacy about the given politics. Moreover, there are instances of the Spanish word "caudillo" (EP15, EP17, NYT14) being used to refer to Chávez, and he is referred to as an example of "populist caudillos" or "messianic caudillos" (EP15). The word "caudillo" denotes a strong and powerful political leader, connoting authori- 
tarianism, and it is an epithet used to describe Spanish fascist leader Francisco Franco. The term "caudillo" is in this sense similar to "populist" because it connotes strong political leadership that deviates from normative liberal forms of governance, but it adds to the discourse on populism by clearly implying Chávez's authoritarianism.

Populism's construction as a form of political deviance is also visible in Chávez's association with other politicians denominated as populists, not the least with contemporary Latin American leftist leaders. An article titled "The populist ghost haunts the region" (EP7) demonstrates how discourses on populism can be tied to deviance from dominant political and economic practices:

One cannot say that there is a great expansion of populism in Latin America. [...] Against such a backdrop, the populists ally themselves with each other.

Like Chávez, his colleague and friend Evo Morales in Bolivia also would be included in this package. Both coincide in steadily increasing the restrictions against private enterprises situated in the country. The appeal to nationalism and to national culture against foreign influences is another common factor. [...]

The "troika" Chávez-Morales is completed by the Nicaraguan president, resurrected former Sandinista leader Daniel Ortega. However, the latter is starting to experience popular discrediting. Not only is he bothered by the increasing influence from the Venezuelan leader (a situation that is shared with Bolivia), but also by his double discourse: radical, anti-imperialist, anti-Spanish and another few antis more in rallies and international forums, but much more moderate in dialogues with businessmen.

The Ecuadorian president Rafael Correa is included in this group. However, the alignment is not total. Like Chávez and Morales he plans constitutional reform, but unlike the Bolivarian he does not talk about indefinite reelection. Nor was he present in the parallel summit to the Latin American [Iberoamericana] one that was held in Chile, orchestrated by Chávez. [...] (EP7)

In the analysis of this excerpt, it is important to pay attention to coherence, essentially the conditional relations between the text's stated facts (van Dijk 1988). Especially relevant here is observing the local coherence of the relationships among the different actors and the characteristics given to them, and how this coherence constructs populism at a more global discursive level.

It is clear from the analysis that the actors constructed as populists in the quoted articleMorales, Ortega, Correa and Chávez-are either known for their association with the radical left or are semantically constructed as having a close relationship with Chávez or at least similar policies. Also supporting this claim is the fact that Argentinean president Nestor Kirchner-who is not generally considered to be a radical leftist-is excluded from this group of populists in the same article. Although it is not stated why he is to be left out, the article highlights "fissures in the relationship Buenos Aires-Caracas" (EP7), which serves as an indirect explanation.

The composition of this populist group thus suggests that, in this example, being a populist goes hand in hand with being a radical leftist, a relationship that is readily apparent in the pairing of Chávez-Morales. Their proposed restrictions on foreign enterprises and their appeal to nationalism are factors that define them as populists. Such a construction in turn suggests that discourse on populism can also integrate opposition to foreign enterprises, which represent global capitalism. In this sense, discourse on populism can also serve for othering actors that oppose global capitalist relations.

The excerpt's discourse also connects populism to deviance from liberal democracy, something that can be discerned from the paragraph about Correa. What discursively attaches Correa to populism is that he, like Chávez and Morales, plans constitutional reform, hence a reformation of a liberal-democratic model. However, one of the reasons why "the alignment is not total" is that he, in contrast to Chávez, is willing to stick to term limits, which is standard in many liberal democracies to avoid power abuse (Held 2006). In this sense, Correa's construction as populist conforms to a liberal democratic perception of democracy. 


\subsubsection{Indirect Constructions of Populism: Paternalism}

As stated above, populism in the media and in everyday speech is broadly characterized by political leadership that appeals to the masses against the elite and/or uses cheap tactics to generate support (Andersson 2009). In the analyzed materials, there are examples that construct the Venezuelan government as acting according to such populist logic-without necessarily explicitly referring to populism. More precisely, such indirect constructions of populism are visible in the ways that the government appears to have a paternalistic relationship with the Venezuelan population's poorer sectors. Such a discourse constructs Chávez as an unusual politician, connects poor Venezuelans' support for Chávez with the country's huge oil revenues, political subsidies and/or selective measures that benefit the poor. In general, such discourse buoys the construction of a government that utilizes the poor's support without necessarily addressing the real needs of the people, which in turn serves to question that government's legitimacy.

For example, a journalistic commentary on Chávez's death states the following:

The political arsenal accumulated in the ballots and the State paternalism towards the poorest population to great part explain the success of the leader from Barinas, who sang, danced and recited in public, assigned and dismissed through television, and dazzled the national machismo by, through the balcony of his palace, announcing the imminence of his sexual relations with María Isabel Rodriguez, his second wife between the years 1999 and 2004: "Marisabel, tonight you will get yours!". Good-natured, seductive, authoritarian, unscrupulous in the attainment of his objectives, nobody obtained such worship among the most needy classes in a nation of 29 million inhabitants that is used to subsidies and prone to providential men. (EP17)

This article explicitly uses the expression "State paternalism" in reference to Chávez's policies, something that coheres to an earlier formulation in the article, when Chávez is said to have had "the fundamental tools" for resurrecting caudillo-style leadership: "an invincible charisma, billions of petrodollars, and more poor than rich people in the electoral roll" (EP17). The excerpt above provides examples of the perceived functionality of this "State paternalism" and how the political leadership connects with the poor. It is clear that an important ingredient in this "State paternalism" is the construction of Chávez as an atypical politician, who dances, sings and even talks about his sexual relations in public. The construction of Chávez as "good-natured" and "seductive" not only serves to capture his unusual manners but also to connect his government style with the needs and expectations of the people, who are characterized as being "used to subsidies and prone to providential men". The references to Chávez as "authoritarian" and "unscrupulous in the attainment of his objectives" thus nurture an understanding of him as a "providential" man and reinforce the construction of "State paternalism" as a form of populism.

Adding to this paternalistic construction are examples of poor people being represented as thankful to Chávez, although they may have reasons not to be satisfied. In an effort to explain the political conjuncture in Venezuela at a uncertain time due to a coming constitutional referendum, a pollster is referred to in EP as saying that "conjuncture elements as the acceleration of inflation and the marked shortages of basic products (as milk, oil, sugar) and other [factors] of longer date as insecurity and kidnappings have not eroded the [Chávez's] strong popularity among the poorer sectors" (EP3). This quotation puts Chávez's support in the context of national problems, suggesting that poor people's presidential loyalty endures despite rather serious problems such as basic products shortages. By not addressing factors that could explain the material basis of Chávez's support-such as poverty reduction-the article instead frames the story to imply that Chávez is not responding to the needs of the people, who are in turn acting against their own interests.

Similarly, the NYT states that:

Though he [Chávez] met opposition at home, he enjoyed broad support, in part by going into the slums to establish health clinics staffed by Cuban doctors and state-run stores 
selling subsidized food. These and other social welfare programs could be corrupt and inefficient, but they made the poor feel included in a society that had long ignored them. (NYT14)

In contrast to the quotation from EP, the $N Y T$ excerpt mentions social welfare programs, such as health clinics and subsidized food, as substantiating Chávez's support. However, in the subsequent sentence, the article notes that such programs "could be corrupt and inefficient", which serves to question these social measures. Also important is how the article describes these measures as making the poor "feel" included, which is not the same as being included. Hence, these measures can be interpreted as government efforts to gain public acceptance rather than effective ways of addressing the people's needs.

In a similar vein, a journalistic commentary states that, "90 percent of the Venezuelans are convinced that the country is rich and that all shortages can be blamed on corrupted politicians. However, no oil revenues in the world can cover free gasoline [...] and Venezuela's expanding subvention network" (DN12). Here, the people are constructed as being misled by the government because they are incapable of understanding what the journalist sees as an unsustainable politics of subventions. Thus, the government acts paternalistically; it gives subsidies yet prevents people from understanding their own best interests. In this way, the government acts according to populist logic.

\subsection{Power Concentration}

As Held (2006) argues, central to the liberal ideal of democracy is a state that is separated from civil society and is formed as an impersonal power structure based on laws. Such ideals date back to Montesquieu's theories of the separation of different power centers-normally the executive, the legislative and the judicial branches-and the implementation of a system of checks and balances that regulate each power center. According to the liberal democratic ideal, such restrictions hinder the concentration of political power in the hands of a few individuals, something that would erode true democratic governance.

The selected materials exhibit macropropositions that serve to construct the Venezuelan government as hoarding political power and neglecting the principle of the separation of powers. Such discourse serves to construct a clash between the practices of the Venezuelan government and what is acceptable within the limits of liberal democracy.

The construction of Chávez as someone with great power-ambitions and that has concentrated much power is palpable in reports about the 2007 constitutional referendum, when Chávez's and the Venezuelan parliament's proposal to change 69 constitutional amendments lost narrowly:

\section{Lawmakers in Venezuela approve expanded power for Chávez}

The National Assembly approved a constitutional overhaul on Friday that would enhance President Hugo Chávez's authority, allowing him to be re-elected indefinitely and giving him the power to handpick rulers, to be called vice presidents, for various new regions to be created in the country. (NYT1)

\section{Chavistas launch campaign for the indefinite reelection in Venezuela (title, EP4)}

Venezuela becomes a 'socialist state', the independence of the central bank is abolished and a new form of local authorities will give the central power more control of what is occurring in the provinces. (DN5)

Taken together, these excerpts show how precedence is given to the proposal aspects that can be interpreted as giving Chávez more power; key lexical choices include "expanded power", "enhance President Hugo Chávez's authority", "giving him the power to handpick rulers", "indefinite reelection" and "more control". This macroproposition's central position is not only visible in the EP and NYT excerpts, where the topic is clearly displayed in the headlines but is also in the lead of the NYT article. Given the summary functions of headlines and leads (van Dijk 1988), the constructions in these two excerpts indicate that issues of political 
power, not only the risk of power abuse, have been given priority in defining news in Venezuela.

The excerpts' discourse attaches the potential power expansion that the overhaul would enable to either Chávez himself, his government or his followers. In the NYT excerpt, the personalization of the alleged power expansion is rather clear from the references to "Chavez" and "him"; the DN excerpt refers to "central power", hence the government, as potentially gaining more power; the EP headline suggests that those belonging to the chavista camp strive for an indefinite reelection. Such constructions serve to negatively frame events in Venezuela, something that is in accordance with the media's focus on negative news stories when covering developing countries (Barry 2012). However, it also helps to construct the Chávez government as deviating from what is democratically legitimate. Expanded presidential or governmental authority strikes a discordant note with popular participation and bottomup power, which are both central ingredients in any conception of democracy. Moreover, focusing on the possibility of a re-election, not least the construction "indefinite" reelection as something associated with Chávez's persona, serves to construct Chávez's alleged power ambitions as deviant from liberal forms of democracy, through which many countries set term limits to safeguard against autocratic power consolidation. Without ignoring that some of the proposals would indeed extend some executive powers, such constructions downplay the fact that if the proposal had passed, the new amendments would have applied to any future president in Venezuela, not only Chávez. The focus on Chávez also blocks further explanations of the proposals' rationales, which further serves to highlight the democratic dangers of the Venezuelan government instead of providing a deeper understanding of these proposals.

Another concentration of power issue concerns the alleged lack of separation of powers in Venezuela. On one level, such constructions are visible in reports on Venezuelan institutions, which are described to be under Chávez's tight control. For example, a news article on the upcoming 2007 referendum states that:

Chávez loyalists already control the National Assembly, the Supreme Court, almost every state government, the entire federal bureaucracy and newly nationalized companies in the telephone, electricity and oil industries. Soon they could control even more. (NYT6)

The excerpt exemplifies something that also can be observed in other newspapers: groups associated with Chávez are constructed as controlling key institutions in Venezuela. Schematically, the excerpt above serves to contextualize the power-balance of Venezuelan politics in an article that highlights the risks of enhancing Chávez's powers in the midst of his promises to redistribute wealth. Assigning the denomination "Chavez loyalists" to those that allegedly "control" the different institutions is important in constructing a situation of power concentration. The abstract and general character of the term "Chavez loyalists" bundles actors or groups from different branches and associates them with Chávez. In this group, we find politicians, judges, public bureaucrats and managers in state-owned companies. As used, the vague term "Chavez loyalists" is sufficiently compelling to construct actors close to the government as the managers of key Venezuelan institutions. Reinforcing this construction is the word "control", which denotes power but says nothing about how the alleged "Chavez loyalists" have attained such political power (for example, by popular vote in the case of the National Assembly). The constructed situation is hence deviant from the normative separation of powers according to the liberal democratic ideal. Especially important here is the construction of the National Assembly and the Supreme Court as controlled by "Chavez loyalists" because this directly heralds a lack of separation between the executive, legislative and judicial powers; hence, according to the liberal ideal, the central power institutions must be separated to avoid an autocratic government.

Presuppositions based on liberal understandings of democracy are also visible in how the lack of separation of powers forms part of journalistic constructions that explicitly evaluate the democratic conditions in Venezuela.

A NYT article adds that "Mr. Chávez also did away with the democratic separation of powers. A pliant legislature granted him the power to dictate laws on his own. Additionally, he 
dominated the judiciary, where loyal judges dependably ruled in his favor" (NYT15). By referring to "the democratic"-in the definite form-"separation of powers" such a discourse fixes the relationship between a core ingredient in the liberal democratic ideal and what is conceived to be more generally democratic. Venezuelan political procedures, as constructed, clearly violate such a standard, and therefore also deviate from what is to be considered truly democratic.

Similarly, liberal-democratic presuppositions are visible in how practices that deviate from agreed-upon democratic ideals are combined with Chávez's socialist aspirations. A news article claims that, "political reforms, colored by a type of autochthonous socialism of difficult definition, ended up giving Chávez absolute control of power in Venezuela" (EP21). The article goes on to say that "Aspects that his own followers uplift as his [Chávez's] principal merits [...] make it clear that the system of checks and balances that the Western democratic political system developed over centuries was nothing he lost sleep over" (EP21). Here Chávez's political reforms, which are said to have given him "absolute control of power", are categorized as a type of socialism, and in turn, conflict with the liberal ideal of a system of checks and balances (Held 2006). In this way, Chávez and his brand of socialism are constructed as deviating from such a system, and the discourse in question serves to laud this traditional liberal model as the alternative to a system of absolute control. In a similar way, a news piece from DN states the following:

Chávez was for long the natural fixed star in this [Latin American] leftist wave. Not least due to that extreme poverty was more than halved in Venezuela, without democratic governance appearing to be seriously threatened.

However, in 2007 Chávez called for a referendum about a socialist constitution. The result was no.

The cult of personality around the president, the increasingly politicized judicature and the direct obstruction by public authorities against the opposition and critical press voices, lead to an increased concern. (DN10)

The excerpt does not construct the reduction of extreme poverty-which is the effect of social policies-as increasing democracy per se. Instead, Chávez's role as a "fixed star" is explained by the coexistence of poverty reduction and democratic governance. The discourse thus separates the struggle for social equality from democratic governance, a view that is closer to a liberal conception of democracy than participatory democracy (Macpherson 1977; Pateman 1970). It is also important that democratic continuity is constructed as being challenged by an eventual socialist constitution; the word "However" marks a break with this continuity. In this way, Chávez's call for a socialist constitution stands against democratic governance. Moreover, the practices mentioned in the subsequent paragraph serve to reinforce Chávez's break with the continuity of democracy. Such alleged practices include a "politicized judicature", indicating a lack of separation of powers, and public authorities' obstruction of oppositional actors, marking partiality among public servants. Such practices, which clearly deviate from the liberal ideals of separation of powers and state formation as an impersonal power structure (Held 2006), are constructed as leading to "increased concern" about democratic governance in Venezuela.

\section{Concluding Remarks}

Seeking to explore how (il)legitimate democracy is constructed in newspaper discourse and relying on foreign news on Venezuela as empirical materials, this study has demonstrated how the media discourse, by associating the Venezuelan government with populism-both directly and indirectly - and with power concentration, constructs that government as deviating from a legitimate democracy. Based on these results, the study has argued that the discourses on populism and power concentration reveal liberal democratic presuppositions, which work together as a normative framework for how the matter's occurrences on are constructed and reported. In this section, I will further discuss the relationship between the iden- 
tified macropropositions, legitimacy and liberalism, and evaluate the implications of such discourse for the news media's capability of informing about democracy.

Although it has been established that the presented macropropositions on populism and power concentration construct deviance from conventional understandings of legitimate democracy, the relationship between such discourse and the concept of legitimacy needs to be further clarified. If legitimacy is something constructed as "legally and morally acceptable" (Chouliaraki 2005, 3), it is not only clear that the presented discourse on populism and power concentration marks deviance from some sort of general democratic acceptability, but it is also needed to underline that legitimacy in the presented materials is more about moral than legal acceptability. Thus, the discourse emphasizes more on what is supposedly right or wrong behavior according to conventional standards than what is legal or illegal in the Venezuelan context. This distinction is very clear in the discourse on populism. Categorization of different political actors as populists and constructions of Chávez's government as paternalist serve to construct these actors as using cheap tactics to win support from society's most vulnerable groups. Moreover, the discourse on power concentration also highlights aspects that are morally contestable: Venezuelan institutions being controlled either by the government or actors loyal to Chávez, something that undermines the possibility of impersonal and transparent state operations. Although it is not constructed in direct violation of any Venezuelan laws, the material certainly constructs such political conduct in conflict with what is morally right. In this sense, these actors are marked as fake democrats who, although legally elected, are contestable on moral grounds. Such a focus thus implies that moral aspects, rather than legal or formal ones, are given precedence in journalistic discourse that assesses these governments' performances.

The ways in which the presented discourse emphasizes moral acceptability very much ties the construction of democratic (il)legitimacy to liberal conceptions of democracy, which in turn unveils the ideological underpinnings of how democracy is perceived. What is constructed as illegitimate democracy thus also deviates from what is morally acceptable according to a general liberal norm. Populism and power concentration are thus discordant with the principle of a neutral and impersonal state and the separation of powers, which is unacceptable according to liberal democratic ideals.

A liberal conception of democracy as a yardstick for defining (il)legitimate democracy in media discourse can at one level indeed be politically healthy. By highlighting the misuse of political power and the risks of leaders' abuses, the news media are at their best acting according to their democratic ideals, and in so doing, fulfilling their watchdog role. However, for the news media to indeed be watchdogs that denounce power abuses, power needs to be understood and contextualized as something more complex than the characteristics of a specific political actor or group of actors. A liberal conception of democracy can for such a task prove insufficient.

As critical scholars point out (Held 2006; Macpherson 1977; Roper 2013), liberal conceptions of democracy take markets for granted, which prevents such a framework from understanding how economic power can distort democracy. In this study, this distortion is visible in how measures to combat poverty are discursively separated from a general view of democracy. Such a conception hence risks reducing power to something that is exercised only within the realm of party politics and fails to grasp the interrelationship between specific political actors' conduct and surrounding socioeconomic structures.

This interrelationship is important because in many countries of the global South, such as Venezuela, the struggle for democratization includes poverty reduction and the politicization of the excluded poor, endeavors that risk neglect in a liberal conception. For example, political scientist Steve Ellner claims that although Chávez's first decade in power fared badly if judged by liberal democratic standards highlighting checks and balances, it was better off if judged on radical democratic standards underscoring mobilization and social justice (Ellner 2010). One of the most important political changes during the Chávez era has been the organization and mobilization of vast numbers of poor people, who have been given an opportunity to participate and voice their opinions. Their voices have been heard through the creation of governmental and non-governmental organizations, such as communal and factory 
councils, social programs and community media, all of which have been sponsored by the state (Artz 2012; Smilde 2011). This reflects the Venezuelan government's revolutionary commitment to promote "the power and action of the working class and its allies as agents of social change" (Artz 2012, 538) to achieve a more just society. As Artz notes, the events in Venezuela, represent the use of the "state for revolution", meaning the dismantling of the old capitalist state and the formation of a new socialist one (Artz 2012, 538-539). And it is in the context of such transformations that one has to evaluate the strengths and shortcomings of Venezuelan democracy. Thus, if political actions are discursively constructed only in relation to liberal democratic standards, where democracy can coexist with vast social inequalities, then only a one-dimensional picture is visible. Moreover, this framework makes it difficult to understand the processes of self-determination in Venezuela. In such a framework, measures for mobilizing the masses can be discarded as mere populism.

Moreover, the interrelationships between political and economic power also suggests that the struggle for democracy is a struggle against the political foundations that enable exploitation and uneven distribution of wealth. In this sense, it is part of the struggle against neoliberal economic policies, and in the long run, against global capitalist relations. The attempts of the Venezuelan government to reduce social inequality by combatting neoliberalism and introducing social programs that help to provide free, universal healthcare and education as well as subsidized food, ought to be seen as democratizing actions. As Lebowitz stresses, the satisfaction of the basic needs of the majority is "the measure by which Venezuelans will judge the Bolivarian Revolution" (Lebowitz 2006, 98).

In turn, this understanding suggests that the use of a specific country's political power and its effects on democracy also need to be dialectically understood in relation to (global) power relations. Without endorsing any possible attempts of power consolidation by Chávez's government, one has to situate its political actions in a context of struggles against national elites who defend their economic privileges and structural positions and against global capitalist structures that keep countries of the global South underdeveloped. Ever since the Venezuelan government started to adopt radical policies that have challenged capital, it has continuously faced an oppositional insurgency and sabotage. Examples of such insurgent actions were clearly exposed during the coup d'état against the Chávez government in April 2002 and the subsequent oil lockout in the end of that same year, which seriously damaged the Venezuelan economy (Lebowitz 2006, 93-98). Additionally, the US government, the US Embassy in Caracas and other agencies, have continuously sent US money to oppositional groups in Venezuela, with the intention of weakening the Venezuelan government and countering the revolutionary process (Golinger 2011). Thus, the struggle for democracy cannot be separated from social struggle or from national and global power relations. This is important to keep in mind a post-Chávez context where the new socialist president Nicolás Maduro was elected by a close margin in 2013, in contrast to Chávez's landslide victories. Conversely, if neglecting such contexts of political and economic power, discourses on democracy instead risk serving to legitimize the existent power-balance of global capitalism (see Moyo 2010; also Duncan 2012). In this respect, the news media does little to act as a watchdog against power, but instead serves to limit the critique of neoliberalism and capitalism in the name of democracy. In this respect, the news media are indeed hegemonic (Gramsci 1971; also Fairclough 1995), because they provide moral and ideological guidance on what democracy is through a framework that generally remains consistent with the dominant economic and political structures. The hegemonic performance of the news media is in turn consistent with the "imperialist character of the media" within the new imperialist world system (Fuchs 2011, 221).

This study has hopefully contributed to an understanding of how discourses on democracy are treated in the media and how this practice is interrelated to legitimacy and liberalism. Nevertheless, to fill some of the current gaps present in the research on democracy as a discursive media practice, I believe that research on how democracy is perceived among journalists and discursively treated in newsrooms is needed and would complement studies on media texts. Such research would contribute to a deeper understanding of how journalists' 
perceptions of democracy shape their own practices and of the consequences for discursive democratic construction in the media.

\section{References}

Aalberg, Toril, Jesper Strömbäck, and Claes H. de Vreese. 2012. The Framing of Politics as Strategy and Game: A Review of Concepts, Operationalizations and Key Findings. Journalism 13 (2): 162178.

Achugar, Mariana. 2004. The Events and Actors of 11 September 2001 as seen from Uruguay: Analysis of Daily Newspaper Editorials. Discourse \& Society 15 (2): 291-320.

Allan, Stuart. 1999. News Culture. Issues in Cultural and Media Studies. Buckingham: Open University Press.

Amin, Samir. 1989. Eurocentrism [Eurocentrisme. English]. New York: Monthly Review Press.

Amin, Samir. 2004. The Liberal Virus: Permanent War and the Americanization of the World [Virus libéral.]. New York: Monthly Review Press.

Andersson, Christian. 2009. Populism. Pocketbiblioteket. 1 uppl ed. Vol. 40. Stockholm: SNS Förlag.

Artz, Lee. 2012. 21st Century Socialism: Making a State for Revolution. TripleC (Cognition, Communication, Co-Operation): Open Access Journal for a Global Sustainable Information Society 10 (2): 537-554.

Badiou, Alain. 2011. The Democratic Emblem. In Democracy in what State? [Démocratie, dans quelle état?]. Translated by William McCuaig, edited by Giorgio Agamben, 6-15. New York: Columbia University Press.

Barry, Marguerite. 2012. Notes from the Semi-Periphery: Ireland's Press Coverage of the Developing World and the Value of Small State Studies in International Communications Research. International Communication Gazette 74 (2): 124-144.

Bensaïd, Daniel. 2011. Permanent Scandal. In Democracy in what State? [Démocratie, dans quelle état?]. Translated by William McCuaig, edited by Giorgio Agamben, 16-43. New York: Columbia University Press.

Boyd-Barrett, Oliver and Terhi Rantanen. 2004. News Agencies as News Sources: A Re-Evaluation. In International News in the 21st Century, edited by Chris Paterson and Annabelle Sreberny, 3145. Luton: University of Luton Press.

Buxton, Julia. 2011. Foreword: Venezuela's Bolivarian Democracy. In Venezuela's Bolivarian Democracy: Participation, Politics, and Culture Under Chávez, edited by David Smilde and Daniel Hellinger, ix-xxii. Durham, NC: Duke University Press.

Cannon, Barry. 2009. Hugo Chávez and the Bolivarian Revolution: Populism and Democracy in a Globalised Age. Manchester: Manchester University Press.

Chomsky, Noam. 2006. Failed States: The Abuse of Power and the Assault on Democracy. New York: Metropolitan Books.

Chouliaraki, Lilie. 2005. Introduction: The Soft Power of War. Legitimacy and Community in Iraq War Discourses. Journal of Language and Politics 4 (1): 1-10; 1.

Curran, James. 2011. Media and Democracy. Communication and Society. Oxford ; New York: Routledge.

D'Eramo, Marco. 2013. Populism and the New Oligarchy. New Left Review 82 (July-August 2013): 528.

Dagens Nyheter. 2014. Om Dagens Nyheter: Om Oss. Accessed May 19, 2014. http://info.dn.se/info/om-oss/

Dimitrova, Daniela V. and Jesper Strömbäck. 2012. Election News in Sweden and the United States: A Comparative Study of Sources and Media Frames. Journalism 13 (5): 604-619.

Duncan, Philip T. 2012. The Discursive Protection of National Interests. Journal of Language \& Politics 11 (3): 357-381.

Ellner, Steve. 2010. Hugo Chávez's First Decade in Office: Breakthroughs and Shortcomings. Latin American Perspectives 37 (1): 77-96.

Ellner, Steve. 2008. Rethinking Venezuelan Politics: Class, Conflict, and the Chávez Phenomenon. Boulder, Colo.: Lynne Rienner.

Fairclough, Norman. 1995. Critical Discourse Analysis: The Critical Study of Language. Language in Social Life Series. London; New York: Longman.

Fairclough, Norman and Ruth Wodak. 1997. Critical Discourse Analysis. In Discourse Studies: A Multidisciplinary Introduction. Vol. 2, edited by Teun Adrianus van Dijk, 258-284. London: Sage. 
Farrelly, Michael. 2008. "Global" Discourses of Democracy and an English City. Journal of Language and Politics 7 (3): 413-430.

Fenton, Natalie. 2012. Telling Tales: Press, Politics, Power, and the Public Interest. Television \& New Media 13 (1): 3-6.

Fuchs, Christian. 2011. Foundations of Critical Media and Information Studies. Routledge Advances in Sociology. Vol. 52. Abingdon, Oxon ; New York, NY: Routledge.

Gan, Faith, Leng Teo Joo, and Benjamin H. Detenber. 2005. Framing the Battle for the White House. Vol. 67.

Garyantes, Dianne M. and Priscilla J. Murphy. 2010. Success Or Chaos? International Communication Gazette 72 (2): 151-170.

Golinger, Eva. 2011. Money and Intervention in Venezuela. Wikileaks: US Embassy Requests Funding for Anti-Chavez Groups. Global Research: Center for Research on Globalization. Accessed August 20, 2014. http://www.globalresearch.ca/money-and-intervention-in-venezuela-wikileaks-usembassy-requests-funding-for-anti-chavez-groups/25444

Gramsci, Antonio. 1971. Selections from the Prison Notebooks of Antonio Gramsci. Translated by Quintin Hoare and Geoffrey Nowell Smith, edited by Quintin Hoare, Geoffrey Nowell Smith. London: Lawrence and Wishart.

Held, David. 2006. Models of Democracy. 3rd ed. Cambridge: Polity Press.

Herman, Edward S. and Noam Chomsky. 2002. Manufacturing Consent: The Political Economy of the Mass Media. New York: Pantheon Books.

Hopmann, David Nicolas, Peter Van Aelst, and Guido Legnante. 2012. Political Balance in the News: A Review of Concepts, Operationalizations and Key Findings. Journalism 13 (2): 240-257.

Human Rights Watch. 2008. A Decade Under Chávez: Political Intolerance and Lost Opportunities for Advancing Human Rights in Venezuela. New York: Human Rights Watch.

Kim, Sung Tae. 2000. Making a Difference: U.S. Press Coverage of the Kwangju and Tiananmen ProDemocracy Movements. Journalism \& Mass Communication Quarterly 77 (1): 22-36.

Laclau, Ernesto. 2007. On Populist Reason. New pbk ed. London ; New York: Verso.

Lebowitz, Michael A. 2006. Build it Now: Socialism for the Twenty-First Century. New York: Monthly review press.

Lebowitz, Michael A. 2010. The Socialist Alternative: Real Human Development. New York: Monthly Review Press.

Macpherson, C. B. 1977. The Life and Times of Liberal Democracy. Oxford: Oxford U.P.

McChesney, Robert W. 2013. Digital Disconnect: How Capitalism is Turning the Internet Against Democracy. New York: The New Press.

McNair, Brian. 2007. An Introduction to Political Communication. Communication and Society. 4th ed. London: Routledge.

Mény, Yves and Yves Surel. 2002. Democracies and the Populist Challenge. New York: Palgrave.

Mouffe, Chantal. 1992. Introduction: Democratic Politics Today. In Dimensions of Radical Democracy: Pluralism, Citizenship, Community, edited by Chantal Mouffe, 1-16. London: Verso.

Moyo, Last. 2010. The Global Citizen and the International Media. International Communication Gazette 72 (2): 191-207.

New York Times. 2014. Who We are: Standards and Ethics. Accessed May 19, 2014. http://www.nytco.com/who-we-are/culture/standards-and-ethics/

Olausson, Ulrika. 2013. The Diversified Nature of "Domesticated" News Discourse: The Case of Climate Change in National News Media. Journalism Studies.

Pateman, Carole. 1970. Participation and Democratic Theory. Cambridge Studies in Sociology (Cambridge U.P.). London: Cambridge University Press.

Roper, Brian S. 2013. The History of Democracy: A Marxist Interpretation. London: Pluto Press.

Smilde, David. 2011. Introduction: Participation, Politics and Culture-Emergent Fragments of Venezuela's Bolivarian Democracy. In Venezuela's Bolivarian Democracy: Participation, Politics, and Culture Under Chávez, edited by David Smilde and Daniel Hellinger, 1-27. Durham, NC: Duke University Press.

Strömbäck, Jesper. 2005. In Search of a Standard: Four Models of Democracy and their Normative Implications for Journalism. Journalism Studies 6 (3): 331-345.

Thussu, Daya Kishan. 2004. Media Plenty and the Poverty of News. In International News in the 21st Century, edited by Chris Paterson and Annabelle Sreberny, 47-61. Luton: University of Luton Press. 
van Dijk, Teun Adrianus. 1988. News as Discourse. Communication (Hillsdale). Hillsdale, N J: L. Erlbaum Associates.

Weisbrot, Mark and Rebecca Ray. 2010. Update on the Venezuelan Economy. Washington: Center for Economic and Policy Research.

Weisbrot, Mark and Luis Sandoval. 2007. The Venezuelan Economy in the Chávez Years. Washington: Center for Economic and Policy Research.

Wodak, Ruth. 2001. What CDA is about-a Summary of its History, Important Concepts and its Developments. In Methods of Critical Discourse Analysis, edited by Ruth Wodak and Michael Meyer, 1-13. London: Sage.

\section{About the Author}

Ernesto Abalo

is a PhD Student in Media and communications at Örebro University, Sweden. His dissertation is on the interrelationship between democratic discourse, ideology and legitimacy in the newspaper coverage of the Bolivarian Revolution in Venezuela. The current article is part of his doctoral project.

\section{Appendix: Corpus for Constructing (II)Legitimate Democracy: Populism and Power Concentration in Newspaper Discourse on Venezuela}

\section{DN 2007}

DN1 - Chávez ändrade grundlagen. DN, 4/11, 2007. Världen, p. 19.

DN2 - Demonstrant dödad i Caracas. DN, 8/11, 2007. Världen, p. 21.

DN3 - Spanske kungen till Chávez: Håll käften! DN, 8/11, 2007. Världen, p. 19.

DN4 - Latinamerikas vänster splittrad. DN, 12/11, 2007. Världen, p. 15.

DN5 - Folkomröstning ska göra Venezuela "socialistiskt". DN, 30/11, 2007. Världen, p. 24.

DN6 - Kupprykten inför omröstning i polariserat Venezuela. DN, 2/12, 2007. Världen, p. 26.

DN7 - Chávez mot seger i Venezuela. DN, 3/12, 2007. Världen, p. 19.

DN8 - Hugo Chávez första nederlag. DN, 4/12, 2007. Världen, p. 18.

EP 2007

EP1 - Choque entre policías y estudiantes en Venezuela. EP, 2/11, 2007. Internacional, p. A3.

EP2 - Parlamento venezolano se pronunció a favor de la reforma de Chávez. EP, 3/11, 2007. Internacional, A4.

EP3 - Chávez no tiene seguro el "sí" a plan constitucional. EP, 4/11, 2007. Internacional, p. E4-E5.

EP4 - Chavistas lanzan campaña hacia reelección indefinida en Venezuela. EP, 5/11, 2007. Internacional, p. A3.

EP5 - Ex ministro de Chávez condena la "reforma". EP, 6/11, 2007. Internacional, p. A3.

EP6 - Poder para el pueblo, según Chávez. EP, 14/11, 2007. Internacional, p. A2.

EP7 - El fantasma populista ronda la región. EP, 25/11, 2007. Internacional, p. E1-E2.

EP8 - Multitud cerró campaña por el "No" en Venezuela. EP, 30/11, 2007. Internacional, p.

A4.

EP9 - La reforma chavista va a las urnas. EP, 2/12, 2007. Internacional, p. E1-E2.

EP10 - Suspenso en el plebicito venezolano. EP, 3/12, 2007. Internacional, p. A2.

EP11 - Polarización y tensión a lo largo de la jornada. EP, 3/12, 2007. Internacional, p. A3.

EP12 - La oposición venezolana le tendió una mano a al presidente Chávez. EP, 5/12,

2007. Internacional, p. A2.

NYT 2007

NYT1 - Lawmakers in Venezuela approve expanded power for Chavez. NYT, 3/11, 2007. P. A 9.

NYT2 - Venezuelan general likens Chavez's proposals for constitution to a coup. NYT, 6/11, 2007. P. A 16.

NYT3 - Gunnmen attack opponents of Chavez's bid to extend power. NYT, 8/11, 2007. P. A 14. 
NYT4 - Students emerge as a leading force against Chavez. NYT, 10/11, 2007. P. A 3. NYT5 - Chavez threatens to reconsider Venezuela's ties with Spain. NYT, 15/11, 2007. P. A 5 .

NYT6 - Chavez vision shares wealth, centers power. NYT, 17/11, 2007. P. A 1.

NYT7 - Protest greet Chavez's pursuit of more power. NYT, 30/11, 2007. P. A 1.

NYT8 - Venezuela: Chavez ready to rule until 2050 [Brief]. NYT, 1/12, 2007. P. A 7.

NYT9 - Venezuela hands narrow defeat to Chavez plan. NYT, 3/12, 2007. P. A 1.

NYT10 - Venezuela vote sets roadblocks on Chavez path. NYT, 4/12, 2007. P. A 1.

NYT11 - For Chavez supporters, many questions after a defeat. NYT, 6/12, 2007. P. A 3.

DN 2013

DN9 - "Chávez blev förgiftad". DN, 6 mars, 2013. Världen, s. 17.

DN10 - Presidenten bröt mot USA:s dominans på kontinenten. DN, 6 mars, 2013. Världen, s. 17.

DN11 - Här tar folket farväl av sin president. DN, 7 mars, 2013. Världen, s. 14-15.

DN12 - Ovisst om nya ledare får nyckeln till folkets hjärta. DN, 7 mars, 2013. Världen, s. 16.

DN13 - "ldoldyrkan är på väg att gå alldeles för långt". DN, 8 mars. Världen, s. 16.

DN14 - Tusentals i kö för att ta farväl av Chávez. DN, 9 mars, 2013. Världen, s. 16.

DN15 - Oppositionella protesterade med kastrullock. DN, 10 mars, 2013. Världen, s. 17.

DN16 - Oppositionen vädrar en möjlighet till seger. DN, 13 mars, 2013. Världen, s. 15.

\section{EP 2013}

EP13 - El talón de Aquiles: la economía se hunde. EP, 6/3-2013. Internacional, p. A6.

EP14 - Chávez deja una fuerza líder con una popularidad del 68\%. EP, 6/3-2013. Internacional, p. A8.

EP15 - Llantos, palabras y una dura lucha de poder en Venezuela. EP, 6/3-2013. Internacional, p. A6.

EP16 - Maduro es el "presidente encargado". EP, 7/3-2013. Internacional, p. A2.

EP17 - El caudillo avasalló y fue imbatible. EP, 7/3-2013. Internacional, p. A6.

EP18 - Caos en una ciudad que siente que debe pagarle una deuda a Chávez. EP, 8/3-

2013. Internacional, p. A2.

EP19 - "Esta banda es de Chávez", dijo Maduro y juró como presidente. EP, 9/3-2013. Internacional, p. A4.

EP20 - Henrique Capriles dice que la juramentación es fraudulenta. EP, 9/3-2013. Internacional, p. A4.

EP21 - Chávez deja en herencia un país partido. EP, 10/3-2013. Internacional, p. E1-E2.

EP22 - Oposicion venezolana teme un fraude. EP, 23/3-2013. Internacional, p. A2.

EP23 - Crecen los chavistas, caen los técnicos. EP, 31/3-2013. Internacional, p. E6.

\section{NYT 2013}

NYT12 - Venezuela Says It's Tracking Opposition Leader in U.S. NYT, 4/3-2013. World, p. A4.

NYT13 - Chávez Dies at 58 with Venezuela in Deep Turmoil. NYT, 6/3-2012. World, p. A1. NYT14 - Hugo Chávez, Leader Who Transformed Venezuela, Dies at 58. NYT, 6/3-2013. World, p. A11.

NYT15 - Chávez Transformed the Way Venezuelans View Themselves. NYT, 7/3-2013. World, p. A10.

NYT16 - A Leader's Cry In Venezuela: 'I Am Chávez'. NYT, 7/3-2013. P. A1.

NYT17 - On Eve of His Funeral, Debating Chávez's Legacy. NYT, 8/3-2013. World, p. A4.

NYT18 - Dignitaries Pay Chávez Tribute, as Venezuelans Express Grief and Misgivings. NYT, 9/3-2013. World, p. A8.

NYT19 - Election to Select New Venezuelan President Is Set for April. NYT, 10/3-2013. World, p. A18. 
NYT20 - Chávez Heir Faces Challenge in Ties With Armed Forces. NYT, 11/3-2013. World, p. A4.

NYT21 - U.S. Expels 2 Venezuela Envoys. NYT, 12/3-2013. World, p. A5. 